\title{
The structure of the Earth's crust of the central part of the Holovanivsk suture zone according to the reinterpretation of materials of IV geotraverse of DSS (PK 295-400)
}

\author{
O.A. Trypolsky, O. V. Topoliuk, O.B. Gintov, 2019
}

Subbotin Institute of Geophysics of the National Academy of Sciences of Ukraine,
Kyiv, Ukraine

Received 21 Desember 2018

\begin{abstract}
Наведено результати переінтерпретації матеріалів, отриманих під час досліджень методом ГСЗ по IV геотраверсу на ділянці ПК 295-400. Переінтерпретацію виконано цілеспрямовано Аля уточнення сейсмічного розрізу в районі Голованівського максимуму сили тяжіння (ПК 320-360). У земній корі на глибинах $2-60$ км додатково виділено сейсмічні площадки і точки дифракції, що дало змогу скласти об'єктивне уявлення про глибинну будову розглянутої частини геотраверсу. Порівняно 3 попередніми інтерпретаціями розріз земної кори значно уточнено. Внаслідок виділення додаткових точок дифракції та великої кількості коротких відбивних елементів на глибинах 2-8 км уточнено положення в розрізі Тальнівської зони розломів. У центральній частині розрізу (ПК 338-ПК 355) на глибинах $8-26$ км установлено серію коротких крутонахилених відбивних елементів. У сукупності з елементами, що мають горизонтальне і похиле залягання (глибини 2-9 і $24-44$ км), вони формують зону середовища, яка на глибинах 2-44 км за характеристиками відрізняється віА вмісних поріА. У результаті простежено лістричну зону сколювання, яка безперервно простягається з глибини 8 км на ПК 355 до 44 км на ПК 304. З урахуванням сейсмотомографічних даних припущено, що Тальнівська зона розломів простежується до глибин $100-600$ км у вигляді межі між блоками з різними швиАкостями $V_{P}$, уступами і розривами в шарі Голицина - Гейка. Поблизу земної поверхні лістрична зона сколювання з'єАнується з основною частиною Тальнівської зони розломів. Згідно з останнім варіантом переінтерпретації Ааних ГСЗ, підвіАний канал інтрузивного тіла гипербазитів на глибинах 60-33 км досить вузький і тільки починаючи $з$ глибини 30 км і майже до поверхні тіло розширюється до товщини близько 15 км. Саме такою є ширина виходів гіпербазитів на поверхню кристалічного фундаменту на ділянці у південному напрямку від геотраверсу IV. Орієнтуючись на зону підвищених швидкостей $V_{P}$ на глибинах $2-33$ км, можна припустити, що саме на цих глибинах уздовж осі центральної частини Голованівської шовної зони розміщується основне тіло інтрузії гіпербазитів і базит-дунітів, перидотитів, піроксенітів, габро, амфіболітів, густина яких перевищус густину вмісних поріА на $0,1-0,22$ г $/ \mathrm{cm}^{3}$.
\end{abstract}

Ключові слова: Голованівська шовна зона, Голованівський максимум сили тяжіння, ГСЗ, IV геотраверс, швидкість поширення сейсмічних хвиль.

Introduction. In terms of studying the deep structure of the lithosphere of the Ukrainian Shield geotraverse IV is the key one because of its location in the territory of almost all megablocks of the shield and the cross section across the stretch of such deep fault zones, as Talnivska, Kryvorizsko-Kremenchutska and Orihovo-Pavlogradska, which define the tectonic zoning of the Ukrainian Shield, and, accordingly, suture zones - Holovanivsk, Inguletsko-Kryvorizka and Orihovo-Pavlogradska. 
Within Pobuzkyi ore area the geotraverse crosses the Holovanivsk high gravity in the latitudinal direction (Fig. 1) and passes near the well-known basic massifs — Troianskyi and Tarasivskyi and slightly to the north of the region of the surface of the crystalline basement of abnormally large amounts (more than 100) areas of serpentine and peridots, which are associated with the development of deposits of silicate nickel and chromites. This has given the interpretation of the seismic data obtained here a lot of weight.

The re-interpretation of the results of the research with the method DSS geotraverse IV was made in early 2000-ies [Trypolsky, Sharov, 2004], and more recently the results of the research method DSS on the part of geotraverse IV the authors deliberately revised in order to clarify the seismic section in the Holovanivsk area of high gravity (PK 320-360). This was provided by a detailed system of observations. In the earth's crust at depths of $2-60 \mathrm{~km}$ from a number of seismic sites and points of diffraction can be obtained that gives the opportunity to build an objective picture of the deep structure of the study of geotraverse. To the west of PK 360 for the lack of a detailed system of observations it was impossible.

In previous interpretations, the seismic section approximately at the depth of the Moho boundary was extended westward to PK 410 [Sollogub, Trypolsky, 1969; Sollogub et al., 1972; Subbotin et al., 1976; Sollogub, 1986; Trypolsky et al., 1984, 1988]. Later, during the reanalysis of seismic materials, this part of the section was partially removed or reviewed [Trypolsky, Sharov, 2004]. The reason for this removal was as follows.

First, in this segment of the seismic pro-

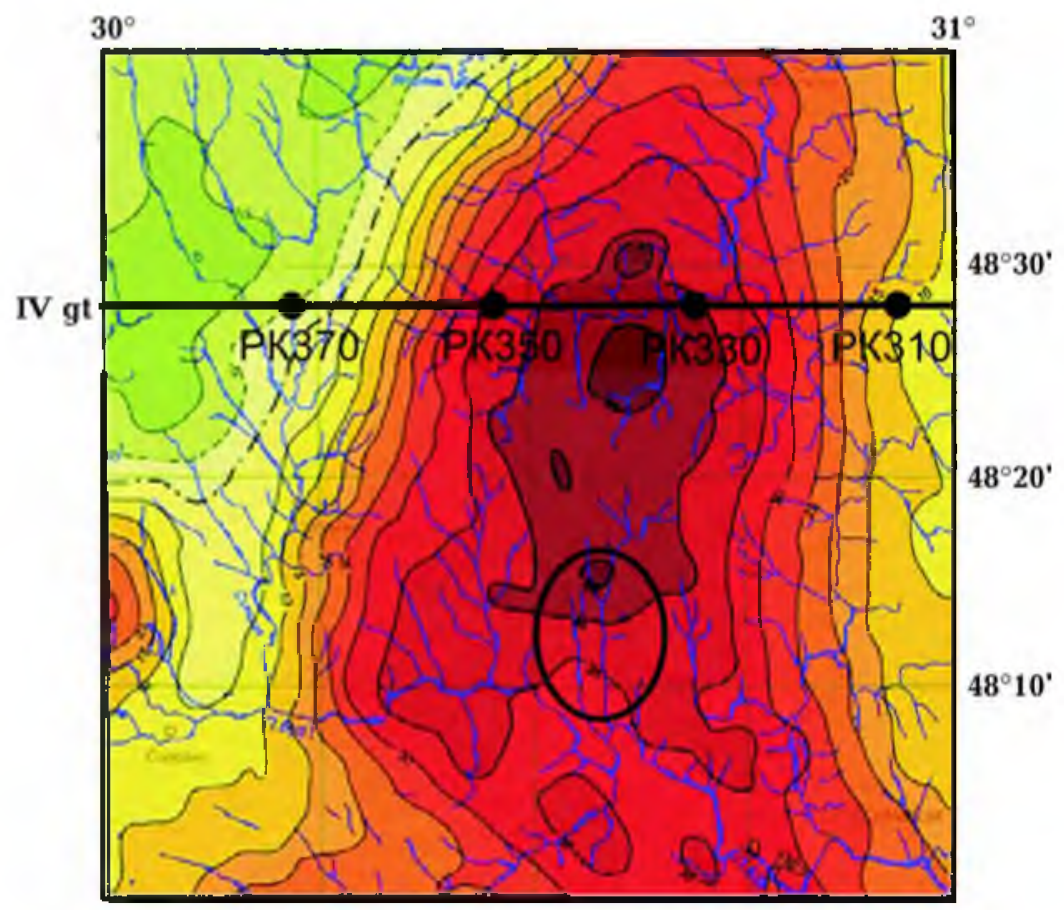

Conditional scale of intensity in milligals

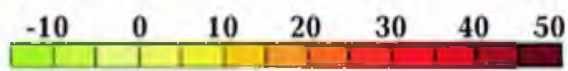

Fig. 1. Schematic map of the gravitational field and the location of the geotraverse IV. The oval contour outlines the area of the exit to the surface of the crystalline basement of the bulk of the bodies of hyperbasites. 


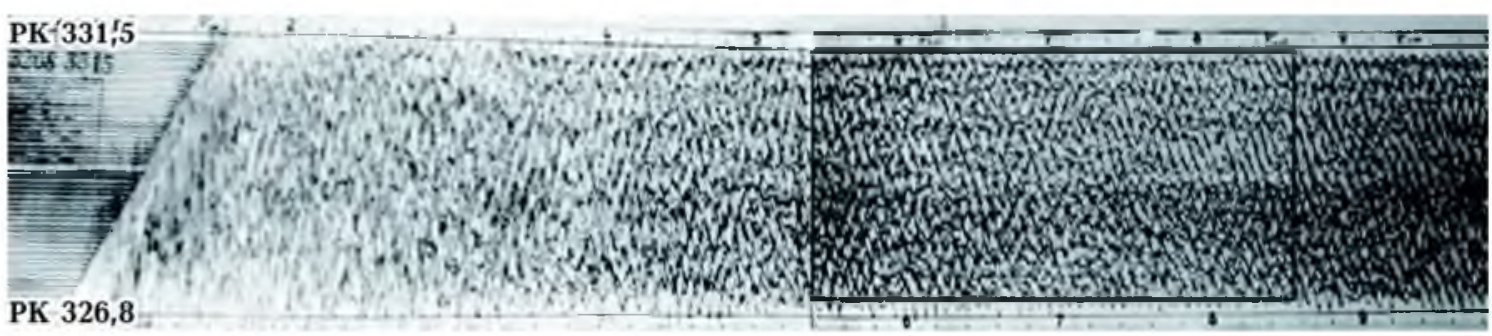

Fig. 2. Seismogram PK 320, PK 326.8-331.5. The rectangle highlights the area where the axes with negative apparent velocities are fixed.

file, work was done under the condition of the lack of a detailed system of observations. Second, a significant part of the deep constructions was carried out due to the partial absence of reverse hodographs, agreed upon at mutual points. This led to the poor quality of the results, which forced to abandon them almost completely.

Observations on geo-traverse IV were carried out by the method of continuous

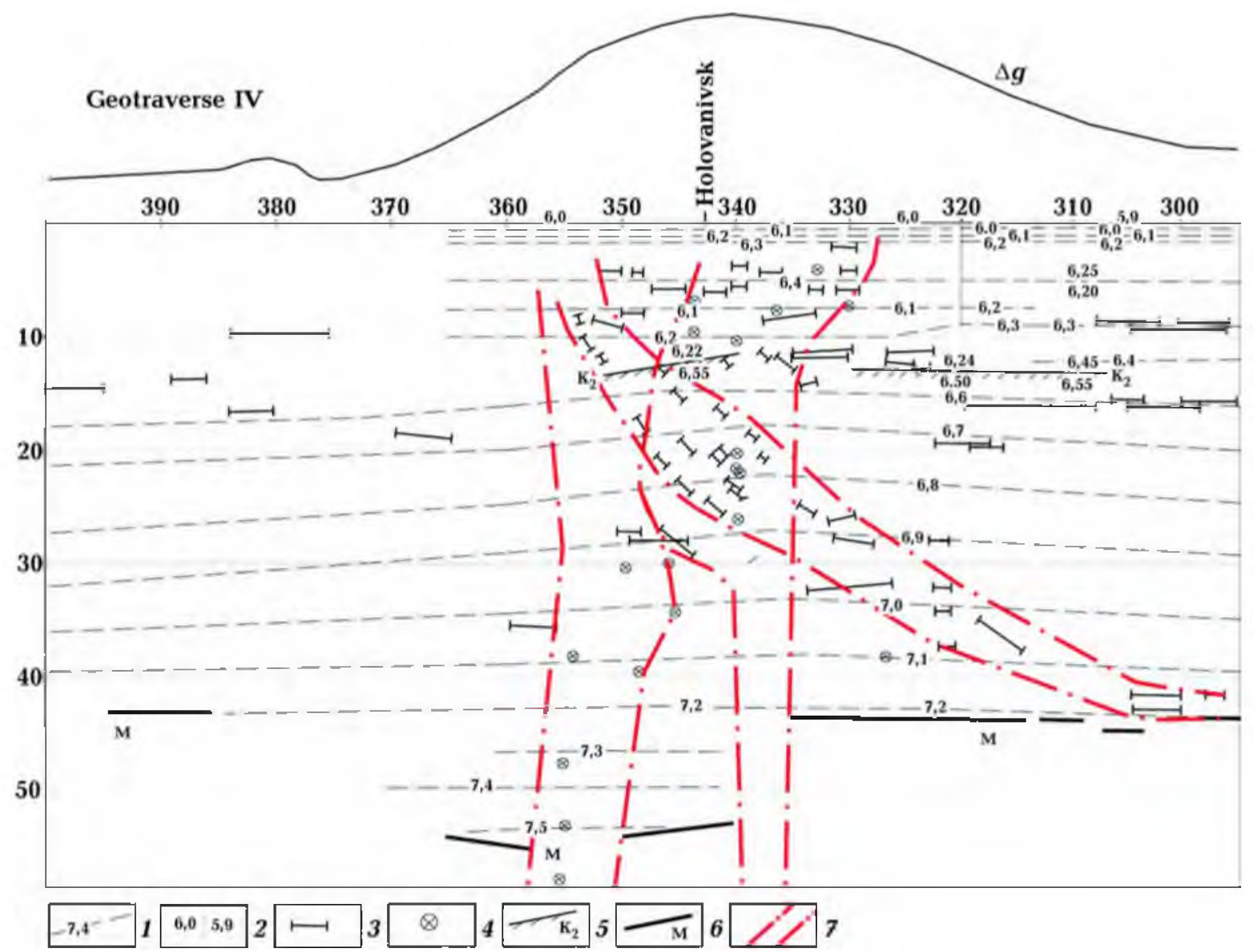

Fig. 3. Seismic section of the Earth's crust along geotraverse IV (PK 295-400): 1 - velocity contours, $\mathrm{km} / \mathrm{s} ; 2-$ conditional boundary separating geotraverse areas with different initial velocities; 3 - reflecting elements in the Earth's crust; 4 - diffraction points; 5 - seismic boundary $\mathrm{K}_{2} ; 6-$ seismic boundary Moho; 7 - deep fault. 
profiling provided for the registration of the system of direct and reverse hodographs of the main waves agreed upon at mutual points. The distance between the explosion points was $20-35 \mathrm{~km}$, the length of continuous hodographs - up to $250-350 \mathrm{~km}$, the distance between the recorders $-100 \mathrm{~m}$.

Under frequency registration are $7-20 \mathrm{~Hz}$ and velocity of propagation of seismic waves in the range $5.7-8.3 \mathrm{~km} / \mathrm{s}$ wavelengths changed in the range of $200-1200 \mathrm{~m}$ (mostly $400-700 \mathrm{~m}$ ). The distance between the recorders was significantly less than half the wavelength that provided a reliable correlation of all waves recorded during field observations.

In general, the section has features that are typical for the most of the DSS profiles in the territory of the Ukrainian Shield. In the upper part of the section at depths of $0-14 \mathrm{~km}$ refracted waves $P_{0}^{\mathrm{K}}$ can be seen everywhere in the distance of $0-80-120$ $\mathrm{km}$ from the point of excitation (Fig. 2).

At depths of $5-13 \mathrm{~km}$ on a segment of PK 295-350 the layer with the lowered velocity below which the seismic boundary $\mathrm{K}_{2}$ that represents a sole of this layer lies is observed. With the exception of this layer, the velocities in the Earth's crust gradually and continuously increase to the depth of the Moho boundary (Fig. 3).

In comparison with previous interpretations of the considered part of geotraverse [Sollogub, 1986, p. 85, Fig. 31; Trypolsky, Sharov, 2004, p. 26, Fig. 9] the section of the Earth's crust is considerably refined.

In the upper part of the Earth's crust (depth $0-5 \mathrm{~km}$ ) velocity compared to their normal values increased (the difference is $0.1-0.2 \mathrm{~km} / \mathrm{s})$. With depth, the measure of velocity increase gradually decreases from $+0.18 \mathrm{~km} / \mathrm{s}$ at a depth of $15 \mathrm{~km}$ to $+0.04 \mathrm{~km} / \mathrm{s}$ at a depth of $40 \mathrm{~km}$.

Velocity in the horizontal direction changes mostly insignificantly. The exception is the area of PK 340-335, where at depths of $18-30 \mathrm{~km}$ there are local maxima of velocities (the area of the deep fault), which corresponds to the maximum of the gravitational curve and may indicate the con- centration at these depths of rocks of more basic composition.

In the time interval between the soles of the layer with reduced velocity and reflected waves from the Moho boundary, supercritical reflected waves from the boundaries lying slightly below the sole of this layer (depths of $13-18 \mathrm{~km}$ ) are recorded. As a rule, the reflected waves from these boundaries are traced parallel to each other in the absence of interference between them (see Fig. 3).

In the Earth's crust in the area of PK $340-355$ at depths of $16-26 \mathrm{~km}$ and $30-$ 40 as a result of registration of diffracted waves, a number of diffraction points are additionally identified. The projection of the diffraction point on the day surface is the minimum of the hodograph. The depth of the diffraction point was determined using a ray diagram.

Diffracted waves are often recorded in deep fault zones of different ranks. Generalization and analysis of DSS materials show that the presence of diffracted waves in the recorded wave pattern is one of the reliable criteria for identifying deep faults in the Earth's crust.

Defining of additional diffraction points, as well as a dense series of short seismic boundaries at depths of $2-8 \mathrm{~km}$ allowed clarify the position of the Talnivska fault zone in the section. On the surface of the crust geotravers crosses it in the area of PK 350-360. A dense series of short seismic boundaries at depths of $2-8 \mathrm{~km}$ can be traced to the east of PK 353. It is impossible to trace it to the west because of the change in the system of observations to a less detailed one. Therefore, considering the position of Talnivska area on the surface [Gintov et al., 2016], in the cut (see Fig. 3) the western limit of the depicted level PK 357. The eastern limit of the zone within the upper part of the crust is not determined through a continuous tectonics destroyed Golovanivsk Suture Zone and the presence of several fault zones, in particular Yemylivska. And in the lower crust, the zone is traced by diffraction points to a depth of 
$60 \mathrm{~km}$ (the zone of rupture in the Moho surface) within the limits of PK 345-355.

It should be noted that the Talnivska fault zone marks the border between the Buzkyi and Rosynskyi megablocks on the one hand and the Ingulskyi [Gintov et al., $2018 \mathrm{a}]$, block on the on the other. According to seismotomographic data [Geyko et al., 2005, p. 935, Fig. 6], this border can be traced at the intersection of $47-50^{\circ}$ of north latitude and at the longitudes $30-$ $31^{\circ}$ east longitude at depths of $100-600 \mathrm{~km}$ in a boundary between blocks with different velocities $V_{P}$ and degrees and gaps in the layer of the Golitsyn-Geyko. Therefore, we can assume that Talnivska area is also seen at these depths. On the surface it is established by brittle-plastic deformation of rocks, and at considerable depths, for example, it is expressed by the structure of the subvertical flow of mantle matter.

Most of the section of the Earth's crust of the considered area of geotraverse IV is characterized, as usual, by horizontal and subhorizontal occurrence of individual seismic boundaries and mainly by a gradual increase in velocity with depth. The exception is the central part of the section (PK $328-355)$, where at depths of $8-26 \mathrm{~km} \mathrm{a}$ series of sharply inclined reflective elements are distinguished.

The method of construction of steeply inclined reflecting elements was as follows. Initially, the beam of the descending wave was reproduced by means of the beam diagram. For this purpose, the zero of the radiation diagram was located at the excitation point (in our case, this is the point of explosion). Next, the beam of the downward wave is reproduced with the start of the reference time on the beam from zero to several seconds. The angle of incidence $(\alpha)$ was calculated according to the formula $\alpha=$ arc$\sin \left(V_{0} / V^{*}\right)$, where $V_{0}$ is the initial velocity, $V^{*}$ is the apparent velocity measured along the line of sight to the element of the hodograph, which corresponds to the site, the depth of which has to be determined. Then the reflected wave beam is reproduced. At the point of exit of the beam to the day sur- face zero beam diagram is placed, from which the time of arrival of the wave along the beam in the direction of decreasing time. The angle of the beam is calculated by the same formula as in the case of a downward wave. At the intersection of these rays there is a reflective element that is normal to the bisector of the angle between them. The length of the reflecting element is 0.5 of the section of the profile on which this element is registered. In our case, due to the registration of waves with negative velocities, the beam of the downward wave is reproduced not in the direction of the registration point of the reflected beam, and in the opposite direction, which corresponds to the negative velocity.

It should be emphasized that the position of sharply inclined reflective elements in the plan is shifted by $10-15 \mathrm{~km}$ in the west direction from the place where they should lie at their horizontal position. This deviation is accompanied by a significant increase in the intensity of reflections from these elements. All these reflecting elements together with horizontally lying elements (depths of $2-9 \mathrm{~km}$ ) form the area of the medium, which at depths of $2-30 \mathrm{~km}$ differs in its characteristics from the host rocks.

The series has one characteristic feature - most of the axes are parallel to each other. This means that the associated reflective elements are likely to be parallel to each other as well. It follows from this conclusion that in the crystalline thickness of the Earth's crust revealed a structure composed of a large number of reflective elements that fall steeply to the east and in general lie quite comfortable.

The physical nature of these reflections can be explained as follows. Reflections are formed only, when the wave on its way meets the change in the acoustic impedance of the medium $\gamma(\gamma=\rho v$, where $\rho$ is the density, $v$ is the velocity, $\mathrm{km} / \mathrm{s}$ ). In this case, the reflection occurs from the boundary, which characterizes the change in the acoustic impedance of the medium. In our case, it can be the surface of some individual layers that divide the medium into separate lay- 
ers, the velocity of which differs from the velocity on their surface. Under this assumption, there are physical prerequisites for the formation of reflections from the surfaces of the layers. It can be assumed that this series is composed of partially parallel bodies with reduced and increased velocities with a predominance of the latter.

A series of inclined reflective elements continues to the west and to the mountains at the level of $8-9 \mathrm{~km}$ under PK 352 , as well as to the east and to a depth of $37 \mathrm{~km}$ under PK 315. This gives one the ability to track the listric zone of shear which continuously extends from a depth of $8 \mathrm{~km}$ on a PK 355 to $44 \mathrm{~km}$ on a PK 304. The zone characterized by width (up to $10 \mathrm{~km}$ ) at depths of $20-24 \mathrm{~km}$, where it coincides with a series of steeply inclined reflective elements and several diffraction points.

Near the surface area the highlighted listric spallation is combined with the main part of the Talnivska fault zone. Tectonophysical studies [Gintov et al., 2016] within the Talnivska zone mapped one several subparallel zones of cleavage of southeast stri$\mathrm{ke}$, one of which is likely to be this listric zone, while others can be traced to a depth of the subvertical ones. Developing the magnetic model of the Earth's crust GSZ, I.K. Pashkevich and M.I. Bakarzhieva [Gintov et al., 2018b, p. 398, Fig. 2.183] already suggested the presence here of the listric zone, which has megablock bug slips under GSZ, or the latter prolonged to Buzkyi megablock.

In the area of PK 335-340, a deep fault along the Moho boundary is known to be recorded, along which it vertically shifts from a depth of $43 \mathrm{~km}$ to a depth of $53 \mathrm{~km}$ (PK 335-340). In addition, a number of diffraction points are allocated in the Earth's crust at the same place (see Fig. 3).

In the context of this section geotraverse, V.B. Sollogub [Sollogub, 1986, p. 85, Fig. 31] allocated intrusive body with high density in the depth interval of $10-50 \mathrm{~km}$ and horizontal dimensions of the body $-3-14 \mathrm{~km}$ at depths of $10-20 \mathrm{~km}$ and $6-14 \mathrm{~km}$ at depths of $20-50 \mathrm{~km}$ at the surface (at a depth of $4-10 \mathrm{~km}$ ) and intrusion deviates to the east and narrows to 3 to $4 \mathrm{~km}$ from the intrusive body, according to the interpretation of V.B. Sollogub, spatially coincides with a vertical deep fracture and gradually narrowing with depth. The fault can be traced to a depth of $50 \mathrm{~km}$.

According to three-dimensional gravity modeling [Starostenko et al., 2018] the degree of section of the Moho depth and the corresponding fault can be traced in $\mathrm{N}-\mathrm{G}$ direction through the central part of the GSZ. In the field of Bouguer anomalies the degree of Moho amplitude up to $10 \mathrm{~km}$ is compensated with increased capacity of crust-mantle mixture in the closed west wing and the largest within the Ukrainian Shield gravitational anomaly (Golovanivsk maximum) due to the raising of the "basalt" and "diorite" of the layers of the plate which have a width of $40 \mathrm{~km}$ is raised with respect to adjacent to $4-10 \mathrm{~km}$. The presence of an intrusive body above the stage of the Moho, supposed by V.B. Sollogub, was not taken into account because of the expected nature of the body and its uncertain power.

According to the latest version of the re-interpretation of DSS data (see Fig. 3) supply channel of intrusive bodies at depths of $60-33 \mathrm{~km}$ is quite narrow and only starting from $30 \mathrm{~km}$ almost to the surface of the body extends to power about $15 \mathrm{~km}$ away. It is the width of the of ultrabasites outcropping at the surface of the crystalline basement in the area south of geotraverse IV (see Fg. 1). Focusing on the region of relatively high velocities $V_{P}$ at depths of 2$33 \mathrm{~km}$ (see Fig. 3), it can be expected that at these depths along the axis of the central part of the GSZ there is the main body of the intrusion of hyperbasites and basitesdunite, peridotite, pyroxenite, Gabro, amphibolite - density which exceeds the density of host rocks is $0.1-0.2 \mathrm{~g} / \mathrm{cm}^{3}$. At the surface at depths up to $2-3 \mathrm{~km}$, the hyperbasites are serpentinized, that is why the intensity of the gravitational field in the region of their cropping out to the surface (see Fig. 3) is slightly reduced. And in places of the outcrops of crystalline basement 
rocks - in Troianskyi and Tarasivakyi areas - there is a maximum intensity of the Holovanivsk anomaly.

Thus, the reinterpretation section of the Holovanivsk section of geotraverse IV significantly clarifies the previous sections, which should be taken into account in the analysis of other geophysical data.

Conclusions. 1. The result of re-interpretation of the data of geotraverse IV in the interval PK $300-400$ a new series of reflection and diffraction points was defined, which gave the possibility to clarify the situation in the context of the Talnivska of the rift and its internal structure, as well as to confirm and clarify the form of the intrusions of basic and ultrabasic rocks predicted by V.B. Sollogub.
2. The considered part of geotraverse IV is characterized by the feature that distinguishes it from other parts - it is a series of steep reflective elements occurring at depths of $8-26 \mathrm{~km}$. Taking into account other inclined and horizontal reflective elements it is possible to trace listric spallation zone of Talnivska fault zone that was assumed here on other geological and geophysical data.

3. It is shown that intrusion of basic and ultrabasic rocks within the Holovanivsk suture zone forms a body with size of about $15 \mathrm{~km}$ width and $30 \mathrm{~km}$ in the vertical part, not taking into account the supply channel. Such a body should be considered in the following quantitative geophysical calculations.

\title{
The structure of the Earth's crust of the central part of the Holovanivsk suture zone according to the reinterpretation of materials of IV geotraverse of DSS (PK 295-400)
}

\author{
O.A. Trypolsky, O.V. Topoliuk, O.B. Gintov, 2019
}

\begin{abstract}
The paper presents the results of reinterpretation of the materials obtained as a result of studies using the DSS method along the IV geotraverse at the site PK 295-400. The reinterpretation was carried out purposefully to clarify the seismic cross section in the area of the Holovanivsk gravity maximum (PK 320-360). A number of seismic sites and diffraction points were additionally identified in the crust at the depths of $2-60 \mathrm{~km}$, which made it possible to form an objective idea of the deep structure of the considered part of geotraverse. The observations were carried out according to the method of continuous profiling, which provided for the registration of a system of direct and inverse hodographs of the main waves, linked at the inter-points. Compared to previous interpretations, the cross-section of the crust was significantly specified. The identification of additional diffraction points and a large number of short reflecting elements at the depths of $2-8 \mathrm{~km}$ made it possible to clarify the position of snaps in the cross section of the Talnivska zone. A series of short steeply inclined reflecting elements was identified in the central part of the cross-section (PK 338-355) at the depth of $8-26 \mathrm{~km}$. Together with horizontally and obliquely lying elements (at the depth of $2-9 \mathrm{~km}$ and $24-44 \mathrm{~km}$ ), they form an environ area that differs according to its features from the host rocks at the depth of $2-44 \mathrm{~km}$, which made it possible to retrace the listric shear zone that continuously extends from the depth of $8 \mathrm{~km}$ at PK 355 to $44 \mathrm{~km}$ at PK 304 . Taking into account the seismic tomographic data, it was suggested that the Talnivska zone of snaps can be retraced to the depth of $100-600 \mathrm{~km}$ as a boundary between blocks with different velocities $V_{P}$ and steps and breaks in the Golitsyn-Geyko layer. Close by the daylight surface, the listric shear zone is connected to the main part of the Talnivska fault zone. According to the latest version of the reinterpretation of the DSS data, the feeder of the intrusive body of hyperbasites is quite narrow at the depth of $60-33 \mathrm{~km}$
\end{abstract}


and expands to a thickness of about $15 \mathrm{~km}$ only starting from $30 \mathrm{~km}$ and almost to the body surface. This is precisely the width of the hyperbasites outbreaks onto the surface of the crystalline basement in the area to the south of the IV geotraverse. Focusing on the area of relatively high velocities $V_{P}$ at the depth of $2-33 \mathrm{~km}$, it can be assumed that the main body of the intrusion of hyperbasites and basit-dunites, peridotites, pyroxenites, gabbro and amphibolites, the density of which exceeds the density of the host rocks by $0.1-0.22 \mathrm{~g} / \mathrm{cm}^{3}$, is located particularly at these depths along the axis of the central part of the Holovanivsk suture zone.

Key words: Holovanivsk suture zone, Holovanivsk gravity maximum, DSS, IV geotraverse, the velocity of seismic waves.

\section{References}

Geyko, V.S., Tsvetkova, T.A., Shumlyanskaya, L.A., Bugaenko, I. V., \& Zaets, L. N. (2005). Regional model 3D $P$ speed mantle of Sarmatia (south-west of the East-European platform). Geofizicheskiy zhurnal, 27(6), 927-939 (in Russian).

Gintov, O.B., Entin, V.A., Mychak, S. V., Pavlyuk, V.N., \& Zultsle, V.V. (2016). Structural-petrophysical and tectonophysical base of geological map of crystalline basement of the central part of Golovanevsk suture zone of the Ukrainian Shield. Geofizicheskiy zhurnal, 38(3), 3-28. https://doi.org/10.24028/gzh. 0203-3100.v38i3.2016.107777 (in Russian).

Gintov, O.B., Orlyuk, M.I., Entin, V.A., Mychak, S. V., Bakirzhieva, M. I., Shimkiv, L. M., \& Marchenko, A.V. (2018a). The structure of the Western and Central parts of the Ukrainian Shield. Controversial issues. Geofizicheskiy zhurnal, 40(6), 3-29. https://doi.org/10. 24028/gzh.0203-3100.v40i6.2018.151000 (in Russian).

Gintov, O.B., Mychak, S.V., Pashkevich, I.K., Bakarzhieva, M.I., \& Lazarenko, O.E. (2018b). Precambrian Ukrainian Shield and plate tectonics. In V. I. Starostenko, O. B. Gintov (Eds), Essays on geodynamics of Ukraine. Kiev: LLC Predpriyatiye VI EN EY (in Russian).

Sollogub, V.B. (1986). Lithosphere of Ukraine. Kiev: Naukova Dumka, 184 p. (in Russian).

Sollogub, V.B., \& Tripolsky, A. A. (1969). Some data on the deep structure of the Earth's crust along the Taganrog-Kirovograd profile. Geofizicheskiy sbornik AN USSR, (31), 5-24 (in Russian).
Sollogub, V.B., Chekunov, A.V., \& Tripolsky, O.A. (1972). Tectonic zoning of the Ukrainian Shield in the light of data of deep geophysical investigations. Geologicheskiy zhurnal, 32(4), 3-10 (in Ukrainian).

Starostenko, V.I., Kuprienko, P.Ya., Makarenko, I. B., Savchenko, A. S., \& Legostaeva, O. V. (2018). Three-dimensional Earth's crust density model of the central part of the Golovanevsk suture zone of the Ukrainian Shield. Geofizicheskiy zhurnal, 40(3), 27-53. https://doi. org/10.24028/gzh.0203-3100.v40i3.2018.137172 (in Russian).

Subbotin, S. I., Sollogub, V. B., \& Chekunov, A. V. (1976). The structure and evolution of the Earth's crust of Ukraine and adjacent regions. Tectonics in the light of new data and views. Geofizicheskiy sbornik AN USSR, (70), 1345 (in Russian).

Tripolsky, A.A., Geyko, V.S., Livanova, L.P., Tripolska, V.A., \& Tsvetkova, T.A. (1988). Seismic model of the Earth's crust. In Lithosphere of Central and Eastern Europe. Geotraverses $I V, V I, V I I I$ (pp. 13-25). Kiev: Naukova Dumka (in Russian).

Tripolsky, A.A., Kvachuk, L.A., \& Tripolska, V.A. (1984). Features of seismic stratification of the Earth's crust of the Kirovograd block. Geofizicheskiy zhurnal, 6(3), 88-94 (in Russian).

Tripolsky, A.A., \& Sharov, N.V. (2004). Lithosphere of the Precambrian Shields of the northern hemisphere of the Earth according to seismic data. Petrozavodsk: Karelian Research Centre RAS, 159 p. (in Russian). 